http://doi.org/10.35784/iapgos.2630

\title{
BROADBAND SATELLITE DATA NETWORKS IN THE CONTEXT OF THE AVAILABLE PROTOCOLS AND DIGITAL PLATFORMS
}

\author{
Jacek Wilk-Jakubowski \\ Kielce University of Technology, Department of Information Systems, Kielce, Poland
}

Abstract. Satellites are a transmission medium for providing connectivity and building global, continental, or regional networks around the world (satellite operators effectively use satellites to support Internet traffic), and point-to-point connections are also possible. In practical use, there are combinations of VSAT networks with terrestrial wireless extensions, allowing end users to increase the capabilities offered with the use of satellite. This paper provides selected information on broadband satellite networks using VSAT technology, including available protocols and transmission platforms. The objective of the article is also to present the chosen technical aspects of satellite networks operating with the use of VSAT technology.

Keywords: information systems engineering, satellite networks, satellite systems, VSAT

\section{SZEROKOPASMOWE SATELITARNE SIECI DANYCH W KONTEKŚCIE DOSTĘPNYCH PROTOKOLÓW I PLATFORM CYFROWYCH}

\begin{abstract}
Streszczenie. Satelity stanowia medium transmisyjne dla zapewnienia łączności i budowy sieci globalnych, kontynentalnych czy regionalnych na całym świecie (operatorzy satelitarni efektywnie wykorzystuja satelity do obstugi ruchu internetowego), przy czym możliwe sa także połaczenia typu punkt-punkt. W praktycznym użyciu sq kombinacje sieci VSAT z bezprzewodowymi rozszerzeniami naziemnymi, co pozwala zwiększyć użytkownikom końcowym możliwości oferowane za pośrednictwem satelity. W artykule zamieszczono wybrane informacje na temat szerokopasmowych sieci satelitarnych $z$ wykorzystaniem technologii VSAT, z uwzględnieniem dostępnych protokołów i platform transmisyjnych. Celem artykułu jest także przedstawienie wybranych aspektów technicznych sieci satelitarnych pracujacych z wykorzystaniem technologii VSAT.
\end{abstract}

Słowa kluczowe: inżynieria systemów informacyjnych, sieci satelitarne, systemy satelitarne, VSAT

\section{Introduction}

In practice, satellite networks are used to provide access to multimedia services as well as to build disaster resilient computer networks. According to a recent research, the expenditure on disaster management is increasing every year [32], and robots are used for disaster management [31]. Besides, satellite networks are the cheapest method for providing global connectivity and communication wherever, for technical (lack of terrestrial infrastructure) and economic reasons, connectivity would be impossible. An example can be seas and oceans, inaccessible areas of taiga or desert, mountainous areas, and many others [33]. In the European Union countries, due to numerous programs aimed at eliminating digital exclusion, satellites are becoming an accelerator of changes aimed at improving the reliability of modern telecommunications systems. In addition to access to numerous multimedia services, it becomes possible to provide access to the Internet with the use of satellite links. For reception, or transmission and reception on the client side, cheap VSAT (Very Small Aperture Terminal) terminals are usually used with antenna diameters usually below $1 \mathrm{~m}$. Besides the antenna, such systems include a receiver with a converter, a modem, cabling, and optionally a router. On the other side, there is an NOC (Network Operations Centre) station. In order to ensure transmission, transponders placed on geostationary satellites are applied. With their use, it becomes possible to transmit data in two ways and to build interactive networks. It is also possible to work with multiple satellites simultaneously and with different frequency bands [34]. During the transmission to VSAT terminals, one of the multiplexing techniques is used. Therefore, the implementation of appropriate modulation, compression, and coding techniques is crucial as described in [35].

Currently, satellite service providers operate their networks at the highest level of redundancy and reliability, which guarantees the Quality of Service (QoS). Figure 1 shows the share of satellite communications operators in the global market. According to Euroconsult data, over ten percent in market share has been recorded for the three largest satellite service operators (SES, Intelsat, and Eutelsat) [14]

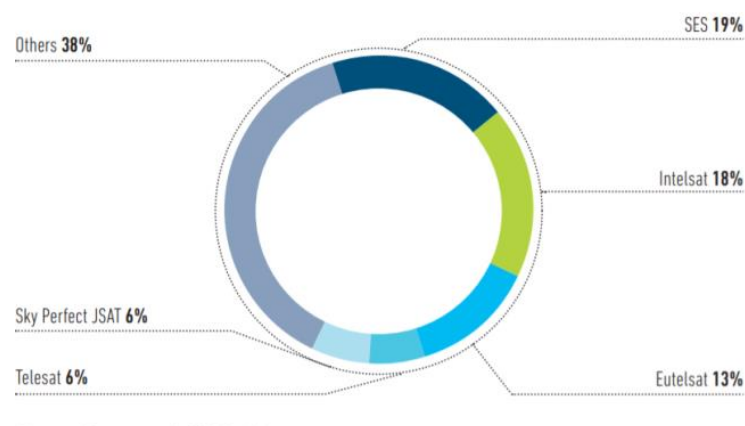

Source: Euroconsult, 2018 edition

Fig. 1. Operator share in the global market based on revenues [14]

Due to multiple layers of redundancy and backup systems, the actual satellite lifetime is close to $100 \%$, and even often exceeds this value. In many cases, these values match or exceed military specifications, making satellite communications the only technology capable of providing communications with a reliability in excess of $99 \%$ (some networks offer $99.9921 \%$ availability).

Since 2013, Federal Communications Commission (FCC) reports presented the transmission speeds offered by satellite communication systems besides DSL technology, fiber optic technology, and cable TV operators' networks [18, 19]. Based on the above reports, it was identified that the actual data rates are typically higher than the declared ones. The differences observed are at the level of $40 \%$ for $90 \%$ of users during PTH (Peak Traffic Hour), which allows to rank the service using satellites at the first place for broadband services offered in the USA.

\section{Literature review including IEEE databases}

Analyzing the literature in the scope of the article, Benjamin A. Pontano presents the possibilities of the Linkway ${ }^{\mathrm{TM}}$ system for $21^{\text {st }}$ century military communications [27]. Gerson Souto and John Stevenson discuss Technical features of the @Intelsat Internet product suite (Intelsat's technical solutions can be found in [28]). Hiroyasu Obata, Kazuya Tamehiro, and Kenji Ishida primarily describe Experimental Evaluation of TCP-STAR for Satellite 
Internet over WINDS [22], Horst D. Clausen and Bernhard Nocker present Internet Services via Direct Broadcast Satellites [11], Hyoung-Kee Choi, Osama Qadan, Dolors Sala, John O. Limb, and Jeff Meyers introduce Interactive Web Service via Satellite to the Home [10]. In addition, the following publications should be indicated as crucial, taking into account the IEEE database: Norman Abramson: Internet Access Using VSATs [1], Leonid Volkov: VSAT Networks of Russian Satellite Communications Company [29], Mamadou A. Barry, James K. Tamgno, Claude Lishou, and Renaud KK Maleka: Challenges of Integrating a VoIP Communication System on a VSAT Network [6], Paul D. Bacsich: JANUS: one year's experience with a TCP/IP VSAT Network [4], Noriharu Suematsu, Suguru Kameda, and Shigeru Eguchi et al.: Multi-Mode Portable VSAT for Disaster-Resilient Wireless Networks [13], Suguru Kameda, Tetsuya Okuguchi, Shigeru Eguchi, and Noriharu Suematsu: Development of Satellite-Terrestrial Multi-Mode VSAT Using Software Defined Radio Technology [24], Tao Huang: A Ka and Ku Band Feed Horn for Satellite Broadband and TV Integrated IP Solution [21]. Additionally, a literature review has been presented below, taking into account domestic publications in this area.

Analyzing the literature on satellite communications, modulation techniques, IP traffic transmission (IP transit both domestic and international) and satellite data communication networks (including VSAT technology), the source of knowledge can be a book [38] by Ryszard Zieliński, published in 2009 and articles by the same author, e.g. [37]. A separate matter is the analysis of the propagation conditions of microwaves in satellite communications. These issues are partly consistent with the research carried out by the author at the Faculty of Electrical Engineering, Automatics and Computer Science of the Kielce University of Technology (the most recent results are from a research entitled: The analysis of solar activity and factors affecting the propagation of microwave signals in the troposphere and satellite signal reception in rainy weather in the area of Kielce, which has been initiated in 2010). Many studies related to the engineering of information systems using VSAT networks, as well as their technical parameters, link budgets, and radio wave propagation were included in the author's monograph [35]. However, due to the subject of this article, these issues are omitted.

\section{Technical aspects of using networks based on VSAT technology}

In the case of using a geostationary orbit, one of the many benefits is that the satellite placed on it is perceived to be stationary relative to the Earth's surface. For this reason, satellite systems in geostationary orbit have simplified satellite tracking devices compared to systems with satellites located in low orbit. These devices are installed in the systems of satellite platform operators. Exemplification can be the largest satellite platform in Central and Eastern Europe - Cyfrowy Polsat S.A. (see Fig. 2).

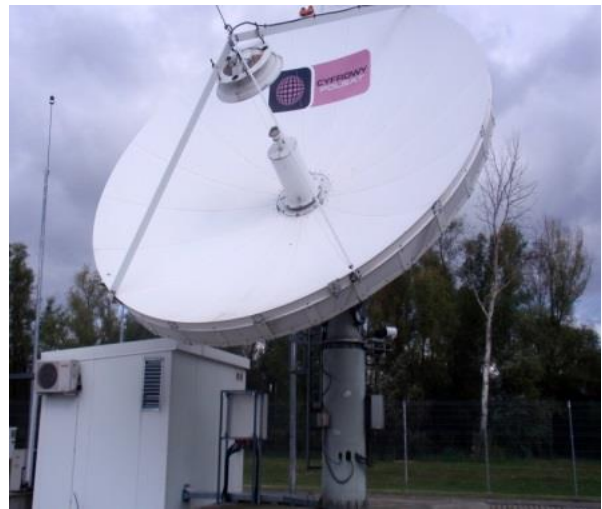

Fig. 2. One of the antennae of the platform Cyfrowy Polsat S.A. (Warsaw)
Although the equipment is located close to the antenna, the position of the satellite can be monitored from the main monitoring center (see Fig. 3).

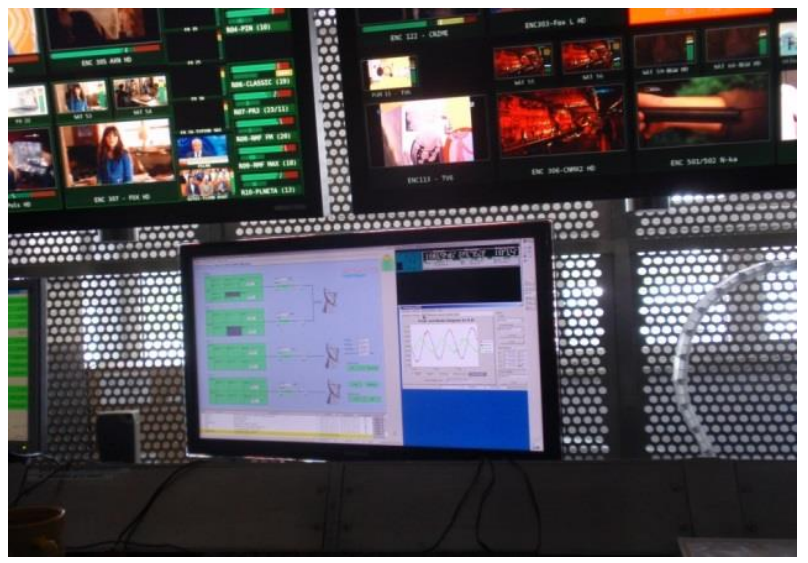

Fig. 3. Monitoring Centre of Cyfrowy Polsat S.A. (Warsaw) [29]

Antennae are oriented in the selected direction, while the position of the satellite in a station keeping window is changing constantly, which translates into the correction of azimuth and elevation angles by satellite traffic engineers (for example, data for two hours for the Ka-Sat satellite are presented in Table 1). It is worth noting that the Ka-Sat is the first HTS (High Throughput Satellite) satellite in Europe and in the Mediterranean Region with considerable capacity and efficiency, operating in the Ka-band [15]. It is anticipated that the advent of satellites in the Ka-band will lead to a reduction in the cost of access to Internet services using satellites in the long term, while increasing bit rates to the levels offered by fibre optic technology.

Table 1. Examples of changes in azimuth and elevation angles, as well as distances from the receiving station for the Ka-Sat satellite (April 2019, adapted from Eutelsat [17])

\begin{tabular}{clll} 
Time(gmt) & Azimuth(deg) & Elevation(deg) & Distance(km) \\
\hline 16:30 & -165.29 & 30.763 & 42157.216 \\
\hline 17:00 & -165.293 & 30.759 & 42160.826 \\
\hline $17: 30$ & -165.294 & 30.756 & 42164.504 \\
\hline $18: 00$ & -165.294 & 30.752 & 42168.186 \\
\hline $18: 30$ & -165.292 & 30.748 & 42171.81 \\
\hline
\end{tabular}

When the position of the selected satellite to the Earth is stabilized, the antennae on board of the directional satellites have a very high energy gain. This results from the need to compensate for signal degradation due to the long distance between the satellite and the ground station. The accuracy of the Ka-Sat keeping window equals $+/-0.1$ degree in elevation and azimuth. The parameters of the satellite's actual position can be determined by using 3D tools. A sample 3D diagram for the Ka-Sat satellite is shown in Figure 4.

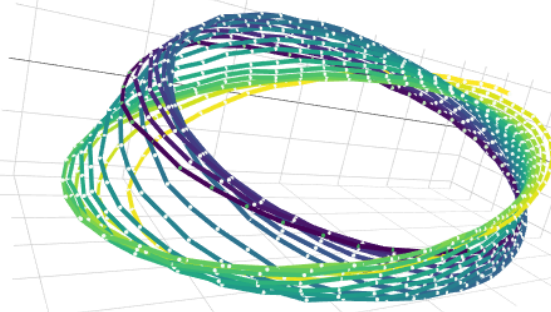

Fig. 4. Examples of three-dimensional visualization of positional changes for the Ka-Sat satellite (adapted from Eutelsat [16]) 
On the other hand, a certain inconvenience is that the use of a geostationary satellite results in significant delays (for example, in corporate networks it is several hundred milliseconds, as the time of each individual hop between the satellite and the Earth is between 120 milliseconds and 140 milliseconds [35]). Undesirable delay affects the use of the TCP (Transmission Control Protocol) /IP (Internet Protocol) protocol stack, which was developed for low delay and low bit error rate terrestrial links [25, 33, 36, 37]. It is difficult to use in both network and transport layers [2]. Information on this will be presented in the next section.

\section{Overview of protocols and digital satellite platforms}

Several types of protocols and transmission platforms are currently used for the provision of broadband multimedia and IT (Information Technology) services, particularly Internet access. In this regard, the following should be pointed out: (1) the TCP/IP protocol stack (protocol tunneling); (2) the DVB-S (Digital Video Broadcasting - Satellite) / DVB-S2 (Digital Video Broadcasting $-2^{\text {nd }}$ generation) platforms; (3) as well as the ATM (Asynchronous Transfer Mode) protocol.

DVB-S digital platform is usually used for multimedia services and data transmission via IP tunneling. A newer standard is DVB-S2, established in 2003. The platform, aside from the specification of protocols, includes, among others: coding of signals based on MPEG (Motion Picture Export Group) standard, providing additional information (mainly for configuration and synchronization of the receiver), protection of data against the impact of undesired factors, i.e. interferences that cannot be predicted using DC (Direct Current) and AC (Alternating Current) analysis methods. Through packet transmission, it is possible to access coded programs in MPEG streams. DVB platforms may be an alternative to VOD (Video On Demand) services available via terrestrial links by distributing content to specific groups of recipients. In the case of Internet services, IP tunneling is applied. In practice, IP packets are subjected to MPE (Multiprotocol Encapsulation) after which they get into DVB transport streams. Because MPE packets are segmented, their size is $184 \mathrm{~B}$ (the additional $4 \mathrm{~B}$ is the MTE packet header). The total container capacity of the DVB-S transport stream is therefore equal to 188 B. The Section Packing (SP) technique aims to improve the encapsulation efficiency of IP packets by placing them optimally in MPEG packets [38]. Sometimes, depending on the interference, it is necessary to change the channel coding, increase the transmitter power, or modify the modulation technique to provide the required QoS level. This often occurs at the expense of reduced data transfer efficiency. DVB-S and DVB-S2 platforms using different modulations allow to transmit data at high speed and to protect the data from errors. The return channel often includes an ATM protocol (the interface may be installed in routers). IP datagrams are encapsulated into packets and then segmented into small ATM cells.

Depending on the type of service, several data transmission profiles can be distinguished: (1) Data Pipe (DP) - used for transmission between end users; (2) Data Streaming (DS) - used for transmission of synchronous, asynchronous or synchronous data streams; (3) Data Carousel (DC) - allows for cyclic transmission of data sets; and the previously mentioned (4) MPE encapsulation, which allows for various types of transport services (IP packet transmissions).

In turn, the use of the ATM protocol, unlike the TCP/IP protocol stack, allows the establishment of a virtual channel between selected points and the transmission of data in cells having a fixed length of $53 \mathrm{~B}$ at rates ranging from about $2 \mathrm{Mbps}$ to about $2.4 \mathrm{Gbps}[9,12]$. Since the cell-tax occupies $5 \mathrm{~B}$, this protocol is not recommended for links with low capacity and data rates. Systems integrated with ATM networks use similar solutions (S-ATM protocol), additionally focused on providing access to the MAC (Medium Access Control) and the physical layer of the link [38]. In comparison to the ATM protocol, the S-ATM protocol has a modified cell-tax format, which is coded redundantly with $\mathrm{BCH}$ (Bose-Chandhuri-Hocquenghen) codes. The advantage of the protocol incluces a guarantee of QoS. Depending on the kind of service in ATM networks, the following transmission types can be distinguished: (1) CBR (Constant Bit Rate) - transmission with uniform bandwidth requirements (e.g., for link emulation); (2) VBR (Variable Bit Rate) transmission of a data stream with variable speed (we can distinguish in this respect: (A) RT VBR - transmission of a data stream with non-uniform distribution of traffic over time; (B) N-RT VBR - transmission of a data stream that does not require real-time support); (3) GFR (Generic Frame Rate) transmission similar to VBR, however the main measure is not cells but frames; (4) ABR (Available Bit Rate) - transmission with undefined bit rate (without significant time requirements) with the possibility of fair bandwidth allocation; (5) UBR (Unspecified Bit Rate) - transmission with undefined bit rate (without transmission quality requirements).

Historically, IP packet encapsulation was applied in ATM cells or transport containers. The overarching goal was to try to use standard protocols with minimal hardware investment. A gateway was responsible for encapsulating traffic from terminals. The implementation of packet techniques influenced the availability of multimedia services and the optimization of the system architecture. In practice, there are numerous network topologies, which are selected depending on the nature of the services provided [34]. The network may be adapted to support the TCP/IP protocol stack, and it is important to ensure the required QoS level, which is done by providing appropriate traffic classification and stream structure. When stations are Web clients, TCP is typically the primary transport protocol. An acknowledgement is awaited before the packet transmission to the remote site is complete, and the network functions as if the delay is the result of congestion in the link. Since this results in packets being sent at a low start rate due to the Slow Start Algorithm (SAA) used, this mechanism is very inefficient [7]. Moreover, when the data is transmitted before the segment length optimization is completed, the transmission will not be realized at close to the maximum speed. To minimize this risk, it is assumed to start the transmission with a double-length segment [38]. Since the time required to achieve the desired throughput can be several hours, the Selective Acknowledge (SACK) mechanism is in common use [38]. The TTL (Time-To-Live) of a datagram is valid for the IP protocol. Due to the fragmentation of IP packets, it is usually not recommended to generate the same datagram for several minutes. Moreover, during the maximum TTL lifetime of a datagram, IP packets that are sent to the same recipient should have different identifiers (timestamps are helpful in this regard). To improve the channel efficiency, some implementations allow to apply the MFWS (Multiplication Factor of Window Size) scaling mechanism. This technique is useful to increase the length of the transmission window by multiplying its size by a certain factor $[23,38]$

In modern satellite network, the process of optimization and acceleration of TCP sessions is performed using PEP (Performance Enhancing Proxies) mechanism that allows modification of TCP headers. This technique is implemented either in the satellite modem software or is made available in the operator resources and hardware on the part of the client and operator. TCP spoofing makes it possible to speed up TCP/IP protocol stack using modern processors, routers, and switches. Reduction of ACK (Acknowledgement) enables an increase in the offered data rate in the satellite links. Acknowledgements are returned quickly, thus hiding significant delays in the link (Fig. 5). 


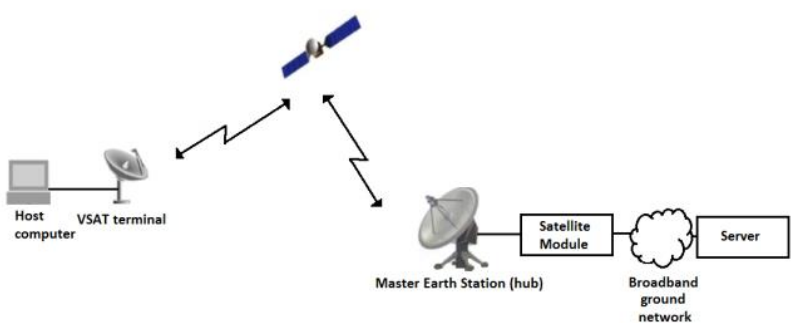

Fig. 5. VSAT network using TCP Spoofing technique

The acknowledgement packets are sent to the local server using the central station module. This reduces the delay, as the data is transmitted to the central station at maximum speed over the terrestrial link. Data transmitted via satellite is buffered. In turn, the VSAT terminal intercepts acknowledgements that are sent at the same time by the host and sends a response to the central station modem. The hardware used is designed to suppress true acknowledgments that arrive from a distant station. When an acknowledgement is not received, the packet is sent from the buffer. The task of the satellite module is removing subsequent packets from the buffer and sending packets (in the case of erroneous packets) to the VSAT terminal. In addition to the TCP protocol, the connectionless UDP protocol is also used in local networks, but is not accelerated due to its connectionless operation. The minimization of the effect of delay on a TCP session is given in Figure 6.
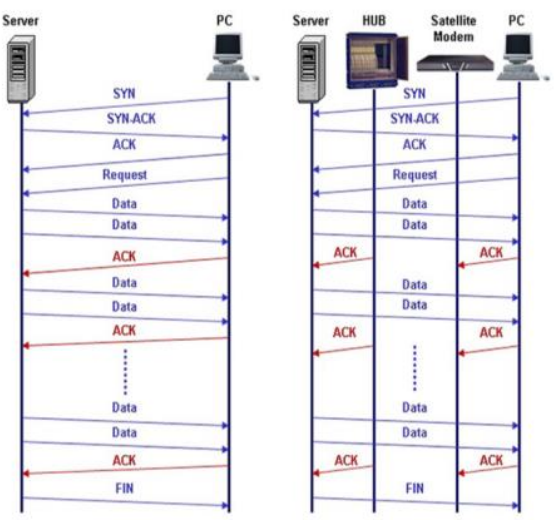

Fig. 6. Illustration of minimizing the impact of delay on a TCP session [38]

The TCP session establishment is based on three packet exchanges that occur between the host and the server (an acceleration example is shown in Figure 7). First, the host sends an SYN request to establish a connection with the server. The server sends an SYN-ACK packet to the host in response to the request, which means that the SYN packet has been received and the server is ready to connect. The host, upon receiving the SYN-ACK packet, sends an ACK-REQUEST packet to the server in order for the server to begin transmission. Due to the significant distance between the satellite and the Earth, the time required to transmit the first packet to the host is long (more than 1 second), which is especially noticeable when transmitting small amounts of data. To counteract this, the acceleration technique is used for WEB applications.

In practice, the VSAT station responds to the SYN packet that was sent by the host by sending an SYN-ACK acknowledgment packet. The request is sent to the server, and then the satellite module in response to the SYN-ACK packet received from the server, using the broadband link, sends an ACK-REQUEST packet to the server. Through a synchronous cheating mechanism between the host and the server, the time required to establish a connection is reduced. This way, data can be sent from the server to the host-coupled VSAT station without unnecessary time delay [38].

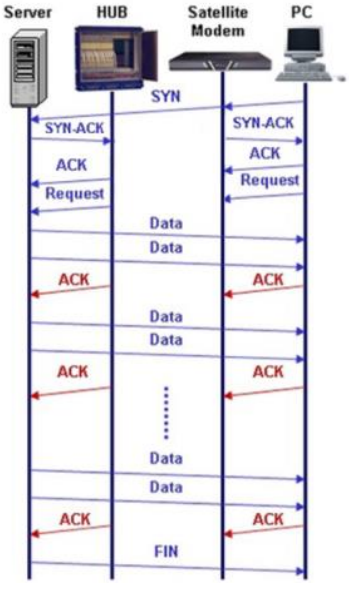

Fig. 7. Illustration of the acceleration technique (own elaboration on the basis of [20])

\section{Conclusions}

Communication satellites are successfully used to provide Internet services from the beginning. Due to fast transmission speeds and the possibility of providing almost global access using satellites without the need for costly terrestrial technical infrastructure, satellite data transmission systems become more and more popular [5, 8].

Many protocols and digital platforms are used for the implementation of broadband services via satellite links. In this respect, there are mainly solutions based on TCP/IP protocol stack (protocol tunneling), ATM protocol, and DVB-S and DVB-S2 platforms. It is worth noting that ETSI (European Telecommunications Standards Institute) standards apply to all types of VSATs. In general, the use of IP protocol is associated with very good availability for many applications, while ATM protocol - with the need to guarantee the required level of transmission quality. Due to the degradation of satellite signals, it is recommended to use adaptive systems, as they allow to ensure the required QoS and to change the modulation technique and increase the channel coding (if necessary). The architecture of broadband systems requires an appropriate design of satellite modules (there are two basic methods of handling data streams: bent pipe and on-board processing and switching). Service providers often use satellite links as backup links. They can be used as access and backbone networks. In the case of connection of remote networks to a main backbone, satellite systems are often the only way to ensure reliability above $99 \%$. Because satellites are designed with multiple layers of redundancy and backup systems, and their lifetimes often exceed $100 \%$, the levels achieved are equal to or even exceed those offered in military specifications.

\section{References}

[1] Abramson N.: Internet access using VSATs. IEEE Communications Magazine 38(7), 2000, 60-68.

[2] Allman M., Glover D., Sanchez L.: Enhancing TCP Over Satellite Channels using Standard Mechanisms. BCP 28, RFC 2488, 1999.

[3] Allman M. (ed.): Ongoing TCP Research Related to Satellites. IETF draft, 1999

[4] Bacsich P. D.: JANUS: one year's experience with a TCP/IP VSAT network IEE Colloquium on Networking Aspects of Small Terminal Satellite Systems, London 1994

[5] Baras J. S., Corson S., Papademetriou S., Secka I., Suphasindhu N.: Fast asymmetric Internet over wireless satellite-terrestrial networks. Monterey 1997.

[6] Barry M. A., Lishou C., Maleka R. K. K., Tamgno J. K.: Challenges of integrating a VoIP communication system on a VSAT network. International Conference on Advanced Communication Technology (ICACT), Bongpyeong 2017.

[7] Becerra A., Berberana I., Gavilán J.: LAN Internetworking Using VSAT Systems. Proceedings of $19943^{\text {rd }}$ IEEE International Conference on Universal Personal Communications, San Diego 1994.

[8] Bobrov A., Bobrov N., Bobrov S.: Organization and economical aspects of satellite networks with asymmetric Internet access. $14^{\text {th }}$ International Crimean Conference Microwaveand Telecommunication Technology, Sevastopoll 2004. 
[9] Charalambous C. P., Frost V. F., Evans J. B.: Performance evaluation of TCP extensions on ATM over High Bandwidth Delay Product Networks. IEEE Communications Magazine 37 (7), 1999, 57-63.

[10] Choi H-K., Qadan O., Sala D., Limb J. O., Meyers J.: Interactive Web Service via Satellite to the Home. IEEE Communications Magazine 39(3), 2001, $182-190$.

[11] Clausen H. D., Nocker B.: Internet services via direct broadcast satellites. IEEE International Performance, Computing and Communications Conference, Phoenix 1997.

[12] Cuevas E. G.: The development of performance and availability standards for satellite ATM networks. IEEE Communications Magazine 37(7), 1999, 74-79.

[13] Eguchi S., Kameda S., Kuroda K., Oguma H., Sasanuma M., Suematsu N.: Multi-mode portable VSAT for disaster-resilient wireless networks. Asia Pacific Microwave Conference (APMC 2014), Sendai 2014.

[14] Euroconsult, 2018 Edition: https://www.eutelsat.com/files/live/sites/eutelsatinternet/files/PDF/investors/2017-18/Eutelsat_Communications_Reference_Do cument_2017-18.pdf (14.09.2018).

[15] Eutelsat: Ka-Sat, URL: https://www.eutelsat.com/sites/eutelsatinternet/home/satellites/9-east.html\#ka-sat (07.06.2016).

[16] Eutelsat: Services, URL: https://services.eutelsat.fr/deploy_Sorbet_SSO/pages/ changeGraphParameters.do (30.04.2019).

[17] Eutelsat: Services, URL: https://services.eutelsat.fr/deploy_Sorbet_SSO/pages/ displaySelectAELocation.do (30.04.2019).

[18] FCC Office of Engineering and Technology i Consumer and Governmental Affairs Bureau, http://www.fcc.gov (31.04.2013)

[19] Gajewski M.: Internet satelitarny przoduje na liście usług szerokopasmowych w USA, https://www.chip.pl/2013/04/internet-satelitarny-przoduje-na-liscieuslug-szerokopasmowych-w-usa (25.04.2013)

[20] Gannon P.: Understanding VPNs over broadband satellite, https://www.bcsatellite.net/blog/understanding-vpn-over-broadband-satellite (21.09.2014)

[21] Huang T.: A Ka and Ku Band Feed Horn for Satellite Broadband and TV Integrated IP Solution. $46^{\text {th }}$ European Microwave Conference (EuMC), London 2016.

[22] Ishida K., Obata H., Tamehiro K.: Experimental Evaluation of TCP-STAR for Satellite Internet over WINDS. $10^{\text {th }}$ International Symposium on Autonomous Decentralized Systems, Tokyo 2011.

[23] Jacobson V., Braden R., Borman D.: TCP Extensions for High Performance. RFC 1323, 1992.

[24] Kameda S., Okuguchi T., Eguchi S., Suematsu N.: Development of satelliteterrestrial multi-mode VSAT using software defined radio technology. Asia-Pacific Microwave Conference, Sendai 2014.

[25] Marchese M.: Performance analysis of the TCP behavior in a GEO Satellite Environment. Computer Communications Journal 24(9), 2001, 877-888.

[26] Mathis N., Mahdavi J., Floyd S., Romanow A.: TCP selective Acknowledgment Options, RFC 2018, 1996

[27] Pontano B. A.: Linkway for $21^{\text {st }}$ century military communications. MILCOM 2000 Proceedings - 21st Century Military Communications. Architectures and Technologies for Information Superiority (Cat. No. 00CH37155), Los Angeles 2000
[28] Souto G., Stevenson J.: Technical features of the @ INTELSAT Internet product suite. IEE Colloquium on Current Developments in Intelsat (Ref. No: 1997/367), London 1997.

[29] Volkov L.: VSAT networks of Russian Satellite Communications Company. $3^{\text {rd }}$ International Conference on Satellite Communications (IEEE Cat. No. 98TH8392), Moscow 1998.

[30] Wilk J. Marciniak M. Systemy geostacjonarne we współczesnej telekomunikacji. Zastosowania technologii informatycznych. Teoria i praktyka. Wydawnictwo Naukowe Instytutu Technologii Eksploatacji - Państwowego Instytutu Badawczego, Radom 2015.

[31] Wilk-Jakubowski G., Harabin R., Ivanov S.: Robotics in crisis management: a review of the literature, submitted for publication. Technology in Society 2020/2021.

[32] Wilk-Jakubowski G.: Normative Dimension of Crisis Management System in the Third Republic of Poland in an International Context. Organizational and Economic Aspects, Wydawnictwo Społecznej Akademii Nauk, ŁódźWarszawa 2019.

[33] Wilk-Jakubowski J.: Information systems engineering using VSAT networks Yugoslav Journal of Operations Research, online first, http://yujor.fon.bg. ac.rs/index.php/yujor/article/view/833 (22.06.2020).

[34] Wilk-Jakubowski J.: Overview of broadband information systems architecture for crisis management. Informatyka, Automatyka, Pomiary w Gospodarce i Ochronie Środowiska - IAPGOS 10(2), 2020, 20-23.

[35] Wilk-Jakubowski J. Ł.: Propagacja fal radiowych w łączności satelitarnej. Radiowaves propagation in satellite communications systems. Wydawnictwo Politechniki Świętokrzyskiej, Kielce 2018.

[36] Yurong H., Lee V. O. K.: Satellite-based Internet: a tutorial. IEEE Communications Magazine 39(3), 2001, 154-162.

[37] Zieliński R. J.: Nowe techniki w systemach VSAT, http://absta.pl/ryszard-jzieliskinowe-techniki-w-systemach-vsat.html (25.07.2019).

[38] Zieliński R. J.: Satelitarne sieci teleinformatyczne. Wydawnictwa NaukowoTechniczne, Warszawa 2009.

\section{Ph.D. Jacek Lukasz Wilk-Jakubowski \\ e-mail: j.wilk@tu.kielce.pl}

Kielce University of Technology, Ph.D. (technical) Faculty of Electrical Engineering, Automatic Control and Computer Science, Department of Information Systems.

Research interests: computer science, ICT systems, data transmission, signal processing, electrical engineering, wave propagation.

http://orcid.org/0000-0003-1275-948X

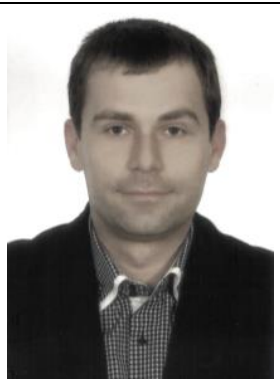

otrzymano/received: 7.04 .2021 przyjęto do druku/accepted: 7.06 .2021 